the Pampas. During the long periods of drought which are so great a scourge to the country, these animals are starved by thousants, destroying, in their efforts to live, every vestige of vegetalion. In one of these siecos, at the tim no less than 50,000 heul of oxen and sheep and horses perished fron starvation and thirst, after tearin deep ont of the soil ever $y$ trace of vegetation, including the wiry roots of the Pampas grass.

Under such circumstances the existence of an unprotected tree is impossible. The only plants that hold their own, in addition to the indestructible thistles, grasses, and clover, are a little herbacens oxalis, producin's viviparous buds of extraordinary vitality, a few poisonous species, steh as the hemlock, and a few tough, thorny, dwarf acacias and wiry rushes, which even a starving rat refuses.

Although the cattle are a molern introduction, the numberless indigenous rodents must always have effectually prevented the introfuction of any other species of plants, large tracts are still honcycombed by the ubiquilous biscacho, a gigantic rabbit, and numerous other rodents still exist, including rats and mice, Pampas hares, and the groat nutria and carpincho on the riverbanks. That the dearth of plants is not due to the unsuitability of the subtropical species of the neighbouring zones, cannot hold good with respect to the fertile valleys of the Andes beyond Mendoza, where a magnificent hardy flora is found. Morenver, the extensive introduction of European plants which has taken place throughout the country has added nothing to the bolany of the Pampas beyond a few species that are unassailable by cattle, such as the two species of thistle which are invading large dis tricts, in spite of their constant destruction by the fires which sways accompany the siccos.

Marlow, January I5 $_{5}$

\section{Japanese Magic Mirrors}

In your last weak's issue (p. 249) appoars a parazraph from a paper by Dr. H. Marro'sa of To'sio on "T'ue M. igie. Mirror of Japen," and reference is mode to the interest these mirror; have excited, and the large num'ser of writera ant lecturers who have taken up the subject of thei constriction. I have read tusst of w'at has been written and staled upon the subject, and disseat from all thet has con: unter my notice, espacially the in zenious theories of non-continuous convexity of surface. My reison for dissent is that I have seen one, and for som tim it was placel in my care by a friend who made it him iclf in this country.

IIe, and I have no doubt corrcctly, assumed that the difference in reflection was due to differcuce of density, and that by ham nering the flat surfaces of the large letters on the back of the mirror, an increased density world he pr.suced which would cxtend to the front of the mirror, which w suld then receive a slightly higher polish, sufficient to give the magical figures. From this reasoning he concluded that any metal which could be polished so as to reflect well could be treated in the same way with the same results.

His first experiment was with a half-crown piece, and the success was complete; he had the reverse rubbed down, until a perfectly smooth and polished surface was profuced, the reflection from which, on white paper and with a strong light, showed the head of the obverse quite distinctly, but diff ring from the magic mirrors in this respect, that it was less bright than th:s other portion of the disk, because the coining-press would bring its greatest pressure upon the field and not upon the type.

Edinburgh

T. C. A.

\section{Peculiar Ice-Forms}

I INCLOSE a letter with which I have been faroured giving another case of the curious ice-structure lately described in Nature. The circamstances are very similar to lhose of the other cnses.

Ilampstea, January i 6

B. WOODD SMITH

\section{Regent Roal, Leicester, January I3, 1885}

DEAk Sik, - Pray excise my trodbling you with an extract from my note-book as to a peculiar form of ice which $T$ saw on the morning of September $2 \mathbf{r}$, 1880. I started to deseend from the Ergi horn hotel a little before 6 , and when $I$ suppuse that I wa about a trousand feet down, just before coming to the word, I noticed so ne curious-looking ice just along the bottom of the sloping sides of the path, which here runs in a shallow gulley two or three feet deep. The ice ran along the side of the path for some yards. I took up several pieces in my hands and examined them, and made a rough sketch, which I reproduce without any additions. The ice was made up of bundles of little rods about onc-sixteenth of an inch in diameter and half an inch long. They were roundish and rough or fluted on their sides, and taperer at each end, and in some cases the end: finisher with a little thread of ice about a quarter the thiciness of the body of the rod. The rods stuck together and were a little curved, and formed roughly two layers, or tiers, one above the other. My note states that these bundles of ice-rods lifted up the dirt and small stones on the top of them. The day before there had been snow with a thaw.

My im ression was at the time that water, rising through the ground and being frozen just bef ore it reached the surface, gave rise to these peculiar ice-forms.

You are quite at liberty to make any use you please of this note.

I am, dear Sir, yours faithfully,

JOHN D. PAUI

\section{Iridescent Clouds}

THE iridescent colours in clouds, observed in England and Scotland in December last, were also visible here' J)ecember 8, 9 , 10, and I2. On the first day, about 3 p.m., the coloured clonds were arranged in a horizontal layer about $20^{\circ}$ high, between $20^{\circ}$ and $80^{\circ}$ azimuth west. In the half altitude a fine stripe broke forth from the background of the ordinary (but not dense) cumulostratus.

The opinion of one of your correspondents that a connection exists between this and the sky-glows of the last two ycars, is contradicted by the circumstance that the phenomenon has been ohserved here several times before, viz. I87I, February 22, March 1, May 10; 1874, January 13; 1875, February 17 I88I, December 27; I882, January II, February 22, July I3 I make the following extract from the observation of 1882 , January $\mathrm{IT}$, showing the peculiar changes in the colours:-a $3.30 \mathrm{p} . \mathrm{m}$. (sun set at 3.20 ) extremcly bcautiful iridescent cirrostratus in south-west, in an altitude of $8^{\circ}-\mathbf{r} 2^{\circ}$. The upper borders, later also the lower, were red, with yellow brims, the rest of the borders and the inner parts very varicgated anc variable ; the lisht red, commonly seen in mothcr-of-pearl, changed through crimson into blue-green, and then into grass green. On some spots this change was repeated twice. The variation of the colours continued till after 4 o'clock; at 4.30 the colour was the ordinary red. The form of the clouds varied very slowly.

I88 $\mathbf{r}$, Deccmber 27 , an isolated brilliantly-coloured cloud was observet through two hours at least. A drawing of it by Dr. Reusch (in wordcut) is inserted in the Norwegian Naturen I882, No. I.

The most striking cases of this phenomenon have been ohserved here when mild and dry wcather set in after frost.

University Obse:vatory, Christiania, Jauuary is

\section{H, GF.T.MUYDEN}

\section{Solar Phenomenon}

As I sec no record of what I witncssed on the afternoon of the I 4 th instant in NATURL of the I5th, I trouble you with this brief statement. At 3h. $20 \mathrm{~m}$. p.m. on that day I was struck by the apyearance of the sun, which was crossed by a light stratus clond of a clcarly-defined ontline, below which appeared what seewed a column of light of uniform width, down to the horizon, the width being somewhat less than the sun's diameter. By 3h. 3 om. the definition of this parallel beam was less marked, but the sun presented to me the appearance of an oblong, suggesting three partially-superposed disks. Soon afterwards the sun was wholly obscired. The day had been cold, the tempera. ture being never far from freceing-point in the shade. I have on former occasions, and in summer, seen the parallel beam striking upwards, once in association with a mock sun.

Valentines, Ilford

C. M. INGLEBY

\section{A Carnibal Snaka}

Wirt reference to !notes as to Ophiophagous sna'xes, which appeared at pp. $216,269,312$, and 408 of the last volume of NATURE, I inclose a communication received by me this morn- 